OPEN ACCESS

Edited by:

Gianvincenzo Zuccotti,

University of Milan, Italy

Reviewed by:

Pasquale Comberiati,

University of Pisa, Italy

Riccardo Castagnoli,

University of Pavia, Italy

*Correspondence:

Giampaolo Ricci

giampaolo.ricci@unibo.it

Specialty section:

This article was submitted to

Pediatric Immunology,

a section of the journa

Frontiers in Pediatrics

Received: 23 April 2020

Accepted: 29 June 2020

Published: 18 August 2020

Citation:

Giannetti A, Bernardini L, Cangemi J,

Gallucci M, Masetti R and Ricci G (2020) Role of Vitamin D in Prevention

of Food Allergy in Infants.

Front. Pediatr. 8:447.

doi: 10.3389/fped.2020.00447

\section{Role of Vitamin D in Prevention of Food Allergy in Infants}

\author{
Arianna Giannetti, Luca Bernardini, Jessica Cangemi, Marcella Gallucci, Riccardo Masetti \\ and Giampaolo Ricci*
}

Department of Paediatrics, S. Orsola-Malpighi Hospital, University of Bologna, Bologna, Italy

The prevalence of food allergy is increasing over the last decades. The role of vitamin D in the prevention of food allergy has been largely investigated. Its role on the physiology of calcium and bone is known, but calcitriol (active form of the vitamin D) also influences the epithelial cells, T cells, B cells, macrophages, and dendritic cells. Almost all cells of the adaptive immune system express the vitamin $D$ receptor, making them also capable of being vitamin responsive. Specifically considering the potential role of vitamins in food allergy, vitamin $D$ has been shown to affect several mechanisms that promote immunologic tolerance, including the $T$ regulatory cell function and the induction of tolerogenic dendritic cells. The target of our review is to evaluate the role of vitamin $\mathrm{D}$ in the prevention of food allergy in children. There are contradictory data on the relationship among the vitamin D deficiency and the developing of food allergy. Some studies associate lower exposure to sunlight to food allergy; on the other hand, further research has found that higher vitamin D levels could increase the likelihood of allergic sensitization and food allergy. Therefore, there is an urgent need for well-planned randomized controlled trials on vitamin $\mathrm{D}$ supplementation, with particular regard to the prevention of food allergy. The role of vitamin $\mathrm{D}$ beyond bone and calcium metabolism is not fully understood.

Keywords: vitamin D, food allergy, prevention, allergic sensitization, immune system

\section{KEY POINTS}

- Vitamin D is a hormone with pleiotropic effects, essential not only for calcium homeostasis and bone mineralization but also for the proper functioning of the immune system.

- However, some patients do not benefit from vitamin D supplementation owing to genetic alterations in metabolism rather than absorption.

- The association between vitamin D and development of food allergy is contradictory.

- There is a potential association between lower sunlight exposure and food allergy, but on the other side, it appears that higher levels of vitamin D might raise the probability of allergic sensitization and food allergy.

- Vitamin D must be considered as a further chance in comprehension and treatment of atopic diseases.

- There is an urgent need for well-planned randomized controlled trials on vitamin D supplementation in food allergy. 


\section{INTRODUCTION}

In recent decades, the occurrence of food allergies has recorded a significant increase in many developed countries worldwide, probably as a result of environmental and lifestyle changes $(1,2)$. Vitamin D is a hormone with pleiotropic effects, essential not only for calcium homeostasis and bone mineralization but also for the regulatory effects on the immune system (Figure 1) (3).

Vitamin D receptors (VDRs) are expressed in almost all the tissues of the human body. There is a significant association between vitamin $\mathrm{D}$ levels and the risk of immunologic, metabolic, or neoplastic disorders (4). Moreover, epidemiological evidence suggests a role of vitamin D in food allergy pathogenesis (5). Vitamin D impacts the function of macrophages, dendritic cells, B cells, T cells, and epithelial cells, playing a key role in immune response, both innate and adaptive $(6,7)$. All these cells convert the circulating prohormone form into the active one. Thanks to vitamin $\mathrm{D}$, the innate response is capable to express antimicrobial peptides_-such as cathelicidin-and plays an important role for keeping mucosal integrity and reinforce epithelial barrier by stimulating junction genes $(8,9)$. Regarding the adaptive immune response, it was found that VDR agonists affect the function of Th1 and Th2 cells, stimulate tolerogenic dendritic cells and regulatory $\mathrm{CD} 4{ }^{+} \mathrm{CD} 25^{+}$Foxp $^{+} \mathrm{T}$ cells, avoid dendritic cell maturation, and abolish allergen-specific IgE synthesis $(10,11)$. In in vitro studies, by exposing human CD4 T cells to $1,25(\mathrm{OH})_{2} \mathrm{D}$, their conversion into IL-10 secreting Treg cells has been proven; at the same time, there is a suppression of IgE making by B cells, with production of antiphlogistic and tolerogenic cytokines $(12,13)$.

In our study, we reviewed the current literature to evaluate the role of vitamin D in food allergy in children.

\section{VITAMIN D PHYSIOLOGY}

In humans, the major source of vitamin $\mathrm{D}(90 \%)$ is the exposure to solar UVB radiation (290-315 nm wavelengths),

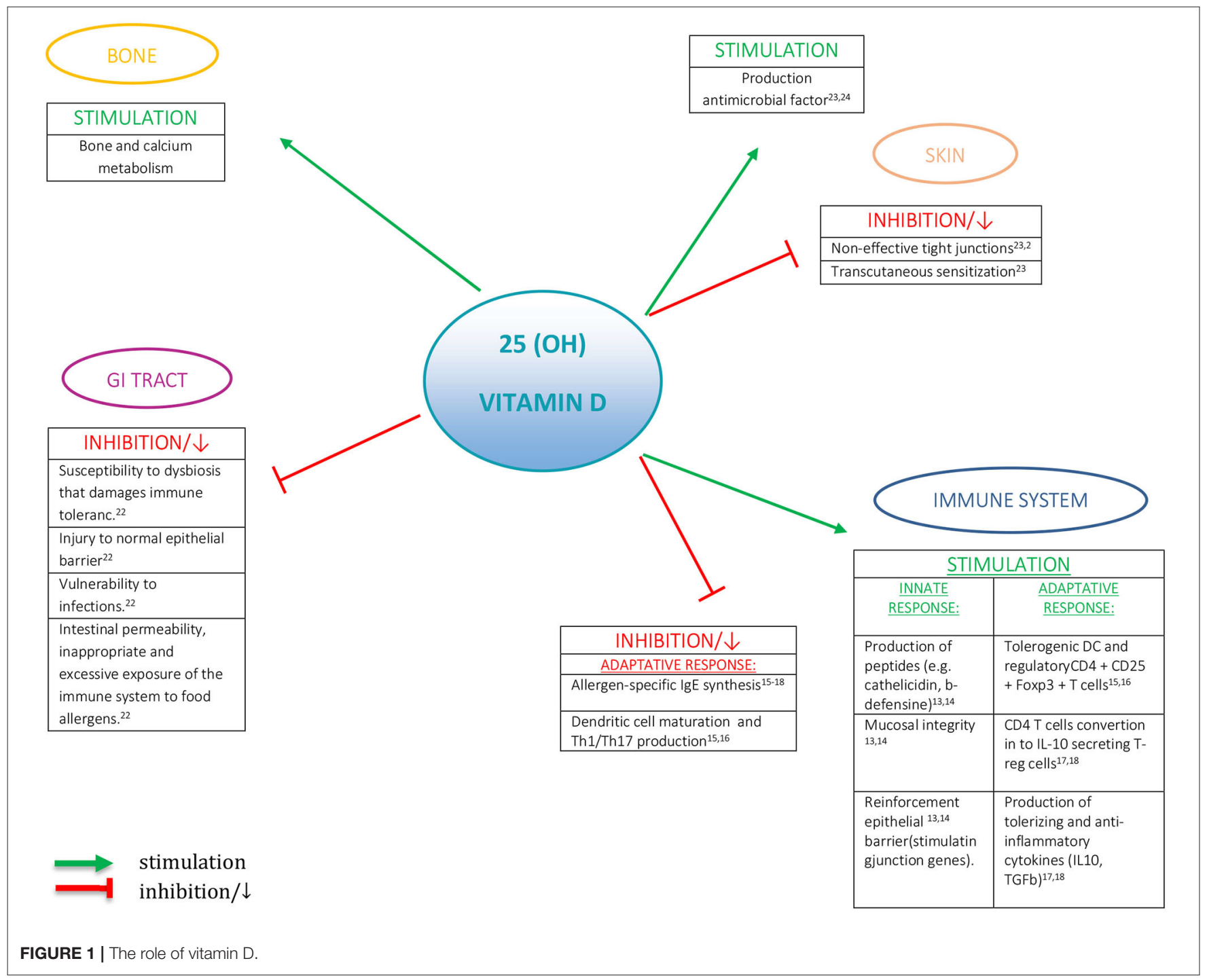


which determines the formation of cholecalciferol in the skin, which is then metabolized in the liver to 25-hydroxyvitamin $\mathrm{D}\left(25-\mathrm{OH}-\mathrm{D}_{3}\right)$ and finally carried to the kidneys, where it is transformed into the active form [1,25-dihydroxyvitamin D, $\left.1,25-(\mathrm{OH})_{2} \mathrm{D}\right](3,14)$. Only $10 \%$ of vitamin $\mathrm{D}$ is obtained through food ingestion.

The best indicator of vitamin $\mathrm{D}$ status is serum $25(\mathrm{OH}) \mathrm{D}_{3}$ levels, which reflect the whole intake of vitamin $\mathrm{D}$, comprehensive sun exposure, integrations, and food intake. In recent decades, it has been observed that there is an increasing evidence of a global vitamin D deficiency (VDD) for all ages $(15,16)$ owing to a combination of extrinsic and intrinsic factors. In the first group, we can include the intensity of exposure to UVB determined by seasons, latitude, altered eating habits, and behavioral factors, without forgetting campaigns to prevent skin cancer, whereas in the latter we might mention the individual level of skin melanin content and the intestinal absorption of vitamin $\mathrm{D}$. Obese people have a greater risk of VDD, caused by their lifestyle and also probably as a consequence of the uptake in the adipose tissue of this liposoluble vitamin (17). However, some patients do not benefit from vitamin $\mathrm{D}$ supplementation owing to genetic alterations in metabolism rather than absorption. In a recent literature review, 35 genes putatively associated with abnormal serum $25(\mathrm{OH}) \mathrm{D}_{3}$ were identified (18).

\section{POTENTIAL ROLE OF VITAMIN D IN THE DEVELOPMENT OF FOOD ALLERGY}

\section{Hypothesis on Pathogenic Mechanisms}

The cellular and molecular mechanisms involved in the pathogenesis of food allergy are very complex and encompass genetic, epigenetic, and environmental factors (19-21). Several mechanisms have been proposed aimed at clarifying the role played by VDD in the food allergy pathogenesis. VDD, at a particular time of life, might increase the susceptibility to colonization by abnormal intestinal microbial flora, contributing to increased intestinal permeability, leading to an inappropriate and excessive exposure of the immune system to food allergens. On the other hand, VDD might cause a disequilibrium at the intestinal level that damages immune tolerance, destroys the normal epithelial barrier, and increases the susceptibility to infections (22). Food allergen sensitization can also be driven by percutaneous sensitization, which may be important particularly in children with VDD (23). It can be speculated that decreased antimicrobial factor and non-effective tight junctions caused by VDD may determine, in the skin, an anomalous exposition and thereby a boost of the immune system, driving to allergic sensitization eczema (24) and the onset of food allergy (23), in addition to an important increase in the severity of atopic dermatitis (25).

The current studies in the literature on the possible role of vitamin $\mathrm{D}$ in the development of food allergy have been reported in Tables 1, 2, which are detailed below.

\section{Evidence on VDD and Anaphylaxis}

The first reports regarding a possible association between food allergy and VDD came from the observation that there was a direct relationship among increasing latitude and cases of anaphylaxis, prescription of epinephrine autoinjector, or food allergy-related admissions (30,40-44). Contrasting results have been reported about the correlation between vitamin $\mathrm{D}$ status and atopic dermatitis severity (45). A recent Korean study (28) compared incidence of food-induced anaphylaxis (FIA) and vitamin $\mathrm{D}$ serum levels between two regions of high and low solar radiation, finding that, in the region of lower solar radiation, vitamin D levels were lower, with concomitantly higher FIA incidence. These findings suggested the possible causal function of vitamin D levels in food allergy, but data sources of FIA and vitamin $\mathrm{D}$ used in the study differed $(27,28,30,40-$ 44, 46). Kim et al. (28) designed a study that included 2,814 patients with FIA and 15,367 people with available serum vitamin $\mathrm{D}$ measurements. After stratification by age, sex, and area of residence, lower solar radiation region had higher FIA incidence (2.2 per 100,000 person-years vs. 1.8 per 100,000 person-years) and lower vitamin $\mathrm{D}$ values (16.5 vs. $17.8 \mathrm{ng} / \mathrm{ml})$ than higher solar radiation region. Camargo et al. (42) examined regional rates of epinephrine autoinjector (EpiPen) prescription in the United States, finding a strong north-south gradient. Mullins et al. (44) evaluated epinephrine autoinjector prescriptions and anaphylaxis hospital admission rates in Australia, used as surrogate markers of anaphylaxis. Both in an unadjusted and adjusted model of children from birth to the age of 4 years, they found a decrease in EpiPen prescription as decreasing absolute latitude. The anaphylaxis admission rates also showed a similar gradient. These data provided additional support and etiologic clues for a possible role of vitamin $\mathrm{D}$ in anaphylaxis pathogenesis. However, we cannot demonstrate that food allergy is linked to vitamin $\mathrm{D}$ levels and not to any other geographic, seasonal, or sunlight-derived factor (47).

\section{Evidence on VDD and Season of Birth}

Other studies showed a relationship between less sunny season of birth and increase of food allergy prevalence. Seasonal differences in UVB exposition result in reduced $25(\mathrm{OH}) \mathrm{D}_{3}$ levels in autumn and winter months; in the higher latitudes, there is no sufficient UVB intensity in the cooler months for proper synthesis of $25(\mathrm{OH}) \mathrm{D}_{3}$ to occur, irrespective of sunlight exposure (27). In addition, there are various data that hypothesize the possible link between season of birth and food allergy. The potential mechanisms are consequential to VDD owing to a paucity of UVB exposure. Matsui et al. (59), in their recent review, proposed the hypothesis that autumn and winter birth could worsen eczema, with the risk of excessive food antigen exposure and sensitization. Moreover, the deficiency of UVB exposure may lead to inadequate Treg expansion, potentially responsible for impaired food tolerance regardless of VDD. VDD resulting from an inadequate vitamin $\mathrm{D}$ synthesis from skin could compromise the intestinal epithelial barrier and antimicrobial peptides, with the risk of intestinal dysbiosis. Lastly, VDD could also modulate immune response and lead to sensitization and impaired food tolerance. Limitations of considered studies are a precise definition of vitamin $\mathrm{D}$ deficiency and the presence of co-factors in the population, such as eczema, skin color, race, residence, skin color, gender, and age. The apparent immune 
TABLE 1 | Summary of studies on the possible role of vitamin $D$ in the development of food allergy.

\begin{tabular}{|c|c|c|}
\hline References & Study & Age, sample \\
\hline Sharief et al. (26) & $\begin{array}{l}\text { Retrospective } \\
\text { study }\end{array}$ & 3,136 children/adolescents and 3,454 adults \\
\hline Mullins et al. (27) & $\begin{array}{l}\text { Retrospective } \\
\text { study }\end{array}$ & $\begin{array}{l}115 \text { peanut allergic patients younger than } 72 \\
\text { months }\end{array}$ \\
\hline Kim et al. (28) & $\begin{array}{l}\text { Retrospective } \\
\text { study }\end{array}$ & $\begin{array}{l}18,181 \text { patients } 10 \text { years or older }(2,814 \\
\text { patients with food-induced anaphylaxis and } \\
15,367 \text { people with available serum vitamin D } \\
\text { measurements) }\end{array}$ \\
\hline Kull et al. (29) & $\begin{array}{l}\text { Prospective birth } \\
\text { cohort }\end{array}$ & $\begin{array}{l}4,089 \text { newborn infants were followed for } 4 \\
\text { years }\end{array}$ \\
\hline Camargo et al. (30) & $\begin{array}{l}\text { Prospective } \\
\text { pre-birth cohort } \\
\text { study }\end{array}$ & $\begin{array}{l}1,194 \text { mother-child pairs followed up through } \\
\text { age } 3 \text { years }\end{array}$ \\
\hline Nwaru et al. (31) & $\begin{array}{l}\text { Prospective cohort } \\
\text { study }\end{array}$ & 971 children with 5-year follow-up \\
\hline Liu et al. (32) & $\begin{array}{l}\text { Prospective birth } \\
\text { cohort study }\end{array}$ & $\begin{array}{l}649 \text { children who were enrolled at birth and } \\
\text { followed from birth onward }\end{array}$ \\
\hline Jones et al. (33) & $\begin{array}{l}\text { Prospective birth } \\
\text { cohort study }\end{array}$ & $\begin{array}{l}231 \text { mother-child pairs, derived from a larger ( } n \\
=669 \text { ) prospective birth cohort, followed up } \\
\text { until } 1 \text { year of age }\end{array}$ \\
\hline Weisse et al. (34) & Prospective & $\begin{array}{l}378 \text { mother-child pairs followed up until } 2 \\
\text { years of age }\end{array}$ \\
\hline Allen et al. (35) & $\begin{array}{l}\text { Australian large } \\
\text { prospective cohort } \\
\text { study }\end{array}$ & 577 infants, 1 year of age \\
\hline Chiu et al. (36) & Prospective study & 186 children (0-4 years) \\
\hline Chawes et al. (37) & $\begin{array}{l}\text { Prospective } \\
\text { clinical study }\end{array}$ & 257 children \\
\hline $\begin{array}{l}\text { Hennessy et al. } \\
\text { (38) }\end{array}$ & $\begin{array}{l}\text { Prospective Cork } \\
\text { BASELINE Birth } \\
\text { Cohort Study }\end{array}$ & $\begin{array}{l}\text { Vitamin D was measured in maternal sera at } 15 \\
\text { weeks of gestation }(n=1,537) \text { and umbilical } \\
\text { cord blood }(n=1,050)\end{array}$ \\
\hline Ercan et al. (39) & $\begin{array}{l}\text { Prospective, } \\
\text { observational, } \\
\text { case-control study }\end{array}$ & 111 children <2 years of age \\
\hline
\end{tabular}

\section{Results}

$25(\mathrm{OH})$ D levels $<15 \mathrm{ng} / \mathrm{ml}$ associated with peanut allergy, no consistent associations seen in adults

Non-linear relationship between neonatal $25(\mathrm{OH}) \mathrm{D}_{3}$ levels and peanut allergy in children under 6 months of age, slightly higher levels (75-99.9 $\mathrm{nmol} / \mathrm{L}$ ) linked with lower vs. those in the reference group (50-74.9 $\mathrm{nmol} / \mathrm{L})$

Higher incidence of food-induced anaphylaxis in regions with lower vitamin $\mathrm{D}$ levels in the population

Water-soluble form increased the risk of allergic disease in children up to the age of 4 years compared with supplementation of same vitamin given in peanut oil

Higher maternal intake of vitamin $\mathrm{D}$ during pregnancy may decrease the risk of recurrent wheeze in early childhood

It was found that maternal intake of vitamin D was inversely associated with sensitization to food allergens

Vitamin $\mathrm{D}$ deficiency may increase the risk of food sensitization among individuals with certain genotypes

Reduced fetal exposure to vitamin $\mathrm{D}$ increases the risk of eczema in infants by 12 months of age

High vitamin $\mathrm{D}$ levels in pregnancy and at birth may contribute to a higher risk for food allergy

Vitamin $D$ insufficiency more likely associated with peanut and/or egg allergy. Vitamin $\mathrm{D}$ insufficiency linked to multiple food allergies $(\geq 2)$ rather than a single food allergy

Cord blood 25(OH)D levels inversely linked with the risk of milk sensitization at 2 years of age

Cord blood $25(\mathrm{OH})$ vitamin $\mathrm{D}$ levels defined as $<50 \mathrm{nmol} / \mathrm{L}$ was not associated with allergic sensitization

The investigators did not observe any association between vitamin during pregnancy or at birth with allergic disease outcomes at 2 and 5 years old

No statistically significant relationship between the CMPA group and healthy controls in terms of $25(\mathrm{OH}) \mathrm{D}$ levels
Definition of vitamin $\mathrm{D}$ deficiency

5 (OH) D deficiency $<15 \mathrm{ng} / \mathrm{ml}$, insufficiency $15-29 \mathrm{ng} / \mathrm{ml}$

Neonatal concentration of $25(\mathrm{OH}) \mathrm{D}$ divided into four groups: <50, 50-74.9, 75-99.9, and $>100 \mathrm{nmol} / \mathrm{L}$. The reference group was considered between 50 and $74.9 \mathrm{nmol} / \mathrm{L}$ Not defined

Not defined

Not defined

Not defined

Cord blood 25(OH) $\mathrm{D}_{3}<11 \mathrm{ng} / \mathrm{m}$

$25(\mathrm{OH}) \mathrm{D}_{3}$ levels cutoffs were divided in $<50$ $\mathrm{nmol} / \mathrm{L}, 50-74.99 \mathrm{nmol} / \mathrm{L},>75 \mathrm{nmol} / \mathrm{L}$

The assay detection limit was defined as $6.7 \mathrm{ng} / \mathrm{ml}$ for maternal $25(\mathrm{OH}) \mathrm{D}_{3}$ and $5.2 \mathrm{ng} / \mathrm{m}$ for maternal $25(\mathrm{OH}) \mathrm{D}_{2}$. Detection limit for cord blood $25(\mathrm{OH}) \mathrm{D}_{3}$ and $\mathrm{D}_{2}$ was $3 \mathrm{ng} / \mathrm{ml}$ Vitamin D insufficiency: $\leq 50 \mathrm{nmol} / \mathrm{L}$

Low vitamin D levels $<20 \mathrm{ng} / \mathrm{ml}$

Cord blood 25(OH)-Vitamin D: deficient, 50 nmol/L; insufficient, $50-75 \mathrm{nmol} / \mathrm{L}$; sufficient, $>75 \mathrm{nmol} / \mathrm{L}$

Maternal $25(\mathrm{OH}) \mathrm{D}$ divided into $<30 \mathrm{nmol} / \mathrm{L}$; $30-49.9 \mathrm{nmol} / \mathrm{L} ; 50-74.9 \mathrm{nmol} / \mathrm{L} ; \geq 75 \mathrm{nmol} / \mathrm{L}$

Vitamin D deficiency $\leq 20 \mathrm{ng} / \mathrm{ml}$, insufficiency $21-29 \mathrm{ng} / \mathrm{ml}$, adequate $\geq 30 \mathrm{ng} / \mathrm{ml}$ 
suppressive effect of ultraviolet radiation is not limited to the supposed inverse relationship between vitamin D levels and FIA rate, but it is also thought to be involved in the development of immune-related disorders, such as type 1 diabetes mellitus (43).

\section{Evidence on VDD and Allergic Sensitization}

The milestone NHANES study (26), based on extensive nationally representative samples from the United States of more than 3,000 children and adolescents, found an association between VDD and higher levels of specific IgE, and thereby allergic sensitization to several allergens, both environmental and food, in children and adolescents, but not in adults. At the same time, the relationship between increased IgE and excessively high vitamin D levels was not confirmed. By contrast, Hypponnen et al. (60), in an adult population study, showed that both low and excessive circulating $25(\mathrm{OH}) \mathrm{D}_{3}$ levels were correlated with an increase in $\operatorname{IgE}$ in a non-linear relationship. Furthermore, higher rates of food sensitization have been seen in infants born to mothers with low vitamin D intake in pregnancy. Nwaru et al. (31) examined the effect of maternal diet during pregnancy on allergic sensitization in a population-based cohort study with 5-years follow-up, by evaluating 971 children with human leukocyte antigen-caused predisposition to type 1 diabetes, for whom maternal pregnancy dietary survey and allergen-specific IgE measurements at 5 years were recorded. The data showed an inverse correlation between sensitization to food allergens and maternal intake of vitamin $\mathrm{D}$, whereas intake of citrus fruits in childbearing might raise the risk of developing allergic sensitization in the sons. A Korean cross-sectional study (49), which included 226 infants [168 infants with atopic dermatitis $(74.3 \%)$ and 58 with suspected food allergy without atopic dermatitis (25.7\%), aged 3-24 months], demonstrated that VDD increased the risk of food allergen sensitization, especially to milk and wheat, but in this work, the diagnosis of food allergy was only suspected and not confirmed by oral food challenge. An Australian large prospective cohort study proved that infants with low vitamin $\mathrm{D}$ levels $\left(25(\mathrm{OH}) \mathrm{D}_{3}<50 \mathrm{nmol} / \mathrm{L}\right)$ at 12 months of age were more likely to be affected by challengeproven food allergy, in particular to peanuts and egg, and to have multiple food allergies, in comparison with those who had appropriate vitamin D levels. Curiously, this connection was clear only among infants of Australian-born parents, hinting a gene-environment interaction (35). However, other studies did not support this evidence (55). Kull et al., in a prospective birth cohort of 4,089 infants, showed that vitamin D in water-soluble form increased the risk of allergic disease in children up to the age of 4 years, compared with supplementation of same vitamin given in peanut oil, but vitamin $\mathrm{D}$ levels were not measured at baseline nor follow-up (29).

In a prospective, observational, case-control study that involved 111 children $<2$ years of age, Ercan et al. (39) assessed the possible link between cow's milk protein allergy (CMPA) and $25(\mathrm{OH}) \mathrm{D}_{3}$ levels in infants with an initial diagnosis of CMPA. Moreover, they also evaluated the association between $25(\mathrm{OH}) \mathrm{D}_{3}$ levels and skin prick test induration size, specific IgE to milk and specific IgE to casein. For the study purpose, they considered vitamin $\mathrm{D}$ deficiency if $25(\mathrm{OH}) \mathrm{D}_{3}$ values were 
TABLE 2 | Summary of review on the possible role of vitamin D in the development of food allergy.

\begin{tabular}{|c|c|c|c|c|}
\hline References & Study & Age, sample & Results & $\begin{array}{l}\text { Definition of } \\
\text { vitamin D } \\
\text { deficiency }\end{array}$ \\
\hline De-Regil et al. (53) & Cochrane review & Variable & $\begin{array}{l}\text { Vitamin D supplementation, during pregnancy, both single-dose or continued, } \\
\text { increased } 25(\mathrm{OH}) \mathrm{D}_{3} \text { levels at term; however, the clinical implication of improving the } \\
\text { vitamin } \mathrm{D} \text { concentration and the possible use of this intervention strategy as part of } \\
\text { the routine antenatal care are yet to be evaluated }\end{array}$ & Variable \\
\hline $\begin{array}{l}\text { Mirzakhani et al. } \\
\text { (54) }\end{array}$ & Review & Variable & $\begin{array}{l}\text { Well-designed and well-powered clinical trials are needed to determine whether } \\
\text { supplementation of vitamin D should be recommended in allergic diseases }\end{array}$ & Variable \\
\hline Willits et al. (55) & Review & Variable & No association between food allergy and vitamin D level & Variable \\
\hline $\begin{array}{l}\text { Yepes-Nuñez et al. } \\
\text { (56) }\end{array}$ & $\begin{array}{l}\text { Systematic review } \\
\text { of randomized and } \\
\text { non-randomized } \\
\text { studies }\end{array}$ & Variable & $\begin{array}{l}\text { Vitamin D supplementation for pregnant women, breastfeeding women, and infants } \\
\text { may not decrease the risk of developing allergic diseases, such as atopic dermatitis } \\
\text { (in pregnant women), allergic rhinitis (in pregnant women and infants), asthma and/or } \\
\text { wheezing (in pregnant women, breastfeeding women, and infants), or food allergies } \\
\text { (in pregnant women). However, they conclude that the potential impact of vitamin D } \\
\text { on food allergy remains uncertain }\end{array}$ & Variable \\
\hline Saggese et al. (57) & Review & Variable & In food allergies, the role of vitamin D remains controversial & Variable \\
\hline $\begin{array}{l}\text { Hawrylowicz et al. } \\
\text { (58) }\end{array}$ & Review & Variable & $\begin{array}{l}\text { Longitudinal studies of vitamin D requirements in utero and post-natally, better } \\
\text { understanding of factors that influence bioavailability of vitamin D, and mechanistic } \\
\text { insights into vitamin D effects on neonatal-specific immune pathways are awaited }\end{array}$ & Variable \\
\hline Matsui et al. (59) & Review & Variable & Fall and winter birth could worse food sensitization & Variable \\
\hline
\end{tabular}

$\leq 20 \mathrm{ng} / \mathrm{ml}$, insufficiency if they were between 21 and $29 \mathrm{ng} / \mathrm{ml}$ and adequate when they were $\geq 30 \mathrm{ng} / \mathrm{ml}$. No statistically significant relationship was found between the CMPA group and healthy controls in terms of $25(\mathrm{OH}) \mathrm{D}_{3}$ levels, nor even milk antigen induration diameter and vitamin D levels of CMPA infants. Hence, they concluded that, at the starting diagnosis of infants with CMPA, routine workup of vitamin D levels may have no benefit. Sardecka et al. (48) examined the relationship between Foxp3mRNA expression (the best marker for Treg lymphocytes) and serum concentration of vitamins D and C, and the development of different phenotypes of tolerance in children with CMPA. The results suggest that increased of Foxp3mRNA expression can predict faster tolerance acquisition in infants with CMA. Regardless of whether they acquire tolerance, children with CMPA have lower serum vitamin D levels than healthy children. Recently, also Guo et al. (51) performed a large observational study involving 2,642 children with the aim of evaluating the correlation between serum $25(\mathrm{OH}) \mathrm{D}_{3}$ and allergic sensitization among childhood 0-2 years of age. Vitamin D was considered insufficient when serum concentration of $25(\mathrm{OH}) \mathrm{D}_{3}$ was $<75 \mathrm{nmol} / \mathrm{L}$ and sufficient otherwise. They did not find evidence supporting the link between low levels of $25(\mathrm{OH}) \mathrm{D}_{3}$ and allergic sensitization to various allergens.

\section{Evidence on VDD, Pre-natal Data, and Birth Cohort Studies}

Another matter investigated by some authors has also been the potential link between $25(\mathrm{OH}) \mathrm{D}_{3}$ concentration in newborns as a marker of risk of future development of food allergies. In the study of Mullins et al. (61) on 115 patients younger than 72 months, it was found that there is an association between peanut allergy and neonatal $25(\mathrm{OH}) \mathrm{D}_{3}$ levels. In comparison with the reference group $(50-74.9 \mathrm{nmol} / \mathrm{L}), 25(\mathrm{OH}) \mathrm{D}_{3}$ levels of 75 to $99.9 \mathrm{nmol} / \mathrm{L}$ were linked to a reduced risk of peanut allergy. At levels of $100 \mathrm{nmol} / \mathrm{L}$ or higher, no additional reduction was found, whereas the probability of peanut allergy at levels lower than $50 \mathrm{nmol} / \mathrm{L}$ was substantially equal to that of the reference group. The risk of peanut allergy at levels $<50$ $\mathrm{nmol} / \mathrm{L}$ was also not significantly different from the reference group. Jones et al. (33) studied the association among cord blood $25(\mathrm{OH}) \mathrm{D}_{3}$ and allergic sensitization, eczema, and food allergy at 1 year of age. The lower vitamin $\mathrm{D}$ levels at birth were associated to higher likelihood of eczema at 12 months, without significant differences between IgE-mediated and nonIgE-mediated eczema. Although in this high-risk subset there was a greater likelihood of IgE-mediated food allergy and allergen sensitization after the first year of life, the probability to develop IgE-mediated food allergy was not linked to cord blood $25(\mathrm{OH}) \mathrm{D}_{3}(33,37)$. Chawes et al. $(37)$, in their Copenhagen Prospective Studies on Asthma in Childhood (COPSAC2000) at-risk mother-child cohort, analyzed the relationship between cord blood 25(OH)vitamin D and asthma and allergy-related conditions during pre-school age in 257 children. After adjusting for season of birth, deficient cord blood $25(\mathrm{OH})$ vitamin $\mathrm{D}$ levels, defined as $<50 \mathrm{nmol} / \mathrm{L}$, were not associated with allergic sensitization. On the other hand, Chiu et al. (36), considering a birth cohort of Taiwanese children, found an inverse relationship between cord blood $25(\mathrm{OH}) \mathrm{D}_{3}$ levels and milk sensitization at the age of 2 years. One hundred eighty-six children aged 0 through 4 years were enrolled and regularly followed up for 4 years. The average cord blood $25(\mathrm{OH}) \mathrm{D}_{3}$ level was $23.8 \pm$ $9.5 \mathrm{ng} / \mathrm{ml}$, with a high occurrence of VDD $(<20 \mathrm{ng} / \mathrm{ml})$ at birth $(42 \%)$. A trend was found between low cord blood $25(\mathrm{OH}) \mathrm{D}_{3}$ levels and higher risk of milk sensitization throughout childhood. At the same time, cord blood $25(\mathrm{OH}) \mathrm{D}_{3}$ levels showed an inverse relationship to the risk of milk sensitization at 2 years old, an age 
at which a greater occurrence of milk sensitization was markedly associated to the risk of asthma development and allergic rhinitis at the age of 4 years. Nonetheless, low cord blood vitamin D levels do not seem linked to a higher risk of allergic rhinitis, eczema, or asthma in early childhood. Hennessy et al. (38), in their Cork BASELINE Birth Cohort Study, investigated associations between intrauterine vitamin $\mathrm{D}$ status and atopic outcomes in an extensively characterized, disease-specific, maternal-infant cohort. In this study, the diagnosis of food allergy was made for all children during the 24-months clinical evaluation visit using skin prick tests. The panel of food allergens included cow's milk, eggs, peanuts, cod, soybeans, and wheat. In the case of wheals with a diameter of $\geq 3 \mathrm{~mm}$, a blinded oral food challenge was completed, if the food had not been eaten previously or if there was a story that suggested the risk of food allergy. The investigators did not observe any association between vitamin D during pregnancy or at birth (measured in maternal sera at 15 weeks of gestation and umbilical cord blood) with allergic disease outcomes (eczema, food allergy, asthma, allergic rhinitis) at 2 and 5 years old. A German study (34) focused on the effects of newborn and maternal vitamin D levels and their influence on the development of food allergy in children, and considered 378 mother-child pairs during pregnancy and at childbirth atopic manifestations during the first 2 years of life by using questionnaires filled out by the parents during pregnancy and annually thereafter. They demonstrated that high vitamin $\mathrm{D}$ levels in pregnancy and at birth might lead to a greater risk of food allergy, suggesting that, to prevent atopy, integration is not required. Recently, Rosendahl et al. (50) realized a randomized controlled trial of daily vitamin $\mathrm{D}$ supplementation of 10 or $30 \mu \mathrm{g}$ from the age of 2 weeks, measuring food and aeroallergen IgE antibodies at 12 months of age. It was demonstrated that high-dose vitamin D supplementation did not prevent allergic sensitization and allergic diseases during the first year of life. On the other hand, it was observed that there is an increased risk of milk allergy in infants randomized to the higher vitamin D supplementation and an increased risk of milk allergy in infants with high cord blood vitamin $\mathrm{D}$ status, thereby suggesting a possible adverse effect of high concentrations of vitamin D. A Cochrane review (53) proved that vitamin D supplementation, during pregnancy, both single-dose or continued, increased $25(\mathrm{OH}) \mathrm{D}_{3}$ levels at term; however, the clinical implication of enhancing the vitamin $\mathrm{D}$ concentration and the possible role of this approach in the standard antenatal care are still to be evaluated because of the limited number of trials and outcomes to deduce implications on safety and efficacy. The presence of mixed results may be a consequence of the gaps in our knowledge about the precise role of vitamin D in the development of food allergy (47). Yepes-Nuñez et al. (56), in a recent systematic review including randomized and non-randomized studies, showed that vitamin $\mathrm{D}$ integration for pregnant women, breastfeeding women, and infants might not reduce the probability of allergic disease development, such as food allergies (in pregnant women), asthma and/or wheezing (in pregnant women, breastfeeding women, and infants), allergic rhinitis (in pregnant women and infants), or atopic dermatitis (in pregnant women). However, they concluded that the potential impact of vitamin $\mathrm{D}$ on food allergy remains uncertain. Liu et al. (32) evaluated the association among cord and maternal vitamin $\mathrm{D}$ level (VDD if cord blood $25(\mathrm{OH}) \mathrm{D}_{3}$ $<11 \mathrm{ng} / \mathrm{ml}$ ) and atopic outcomes in 649 children recruited at birth and followed from then on, and found that VDD alone was not related with food sensitization. If examined together with SNPs, a significant interaction was found between VDD and IL-4 gene polymorphism. VDD raised the risk of food sensitization among children carrying CC/CT genotypes; comparable but lower relationships were seen for the SNPs. The conclusion of their study is that VDD may enhance the risk of food sensitization among people with specific genotypes. A recent longitudinal Icelandic study, involving 144 children followed up for 6 years, compared infant feeding with particular regard to vitamin $\mathrm{D}$ supplementation and $25(\mathrm{OH})_{3}$ levels between IgE-sensitized and non-sensitized children at 6 years. They found that, at 1 year of age, IgE-sensitized children had a reduced intake of vitamin D, partially explained by a reduced, but non-significant, vitamin $\mathrm{D}$ supplement use and reduced consumption of vitamin $\mathrm{D}$ fortified formula. At 6 years, less IgE-sensitized children used vitamin D supplements regularly. Equally, vitamin D integration at 6 years decreased the ratio of $\operatorname{IgE}$ sensitization (52). Nonetheless, the authors did not record a difference in mean serum $25(\mathrm{OH}) \mathrm{D}_{3}$ between IgE-sensitized and non-sensitized children, nor at 12 months (96.8 \pm 33.6 vs. $99.3 \pm 32.2 \mathrm{nmol} / \mathrm{L}$, respectively) or 6 years $(59.3 \pm 15.9$ vs. $56.0 \pm 16.7 \mathrm{nmol} / \mathrm{L}$, respectively). In conclusion, their data encouraged, for Nordic infants and children, vitamin D intake from diet and supplements.

Further issues are about the definition of optimum, deficiency, and insufficiency vitamin D serum levels, not worldwide recognized and rather specific for bone outcomes, but not for global health effects $(4,6)$. Low vitamin D levels are common in healthy newborns $(33,62)$ and are independently associated with various factors (skin color, diet, maternal levels and intake, supplements, and seasonality) and strengthen the controversy on the benefits of providing vitamin D integration during infancy.

\section{CURRENT SCENARIO}

The current reviews $(54,56-59)$ conclude that further studies are needed to evaluate the association between allergy and vitamin D. Vitamin D supplementation controlled studies aimed to clarify its role in food allergy development are still lacking.

Currently, there are more evidence to support vitamin D supplementation in pregnancy and infancy, in light of its positive effects. In fact, VDD may boost the risk of food allergy and sensitization among people with particular genotypes (32). Nevertheless, when studied alone, VDD was not associated with food allergy whereas, on the other hand, it was significantly related with specific gene polymorphisms, supplying evidence on food allergy. Also, the role of vitamin D beyond bone and calcium metabolism is not fully understood.

\section{CONCLUSIONS}

The role of vitamin $\mathrm{D}$ beyond bone and calcium metabolism is alluring but not fully understood. The association between 
vitamin $\mathrm{D}$ and development of food allergy is contradictory (Tables 1, 2).

Potential relationships come from ecologic studies that associate lower sunlight exposure to food allergies. On the other hand, further research found that higher levels of vitamin D might raise the probability of allergic sensitization and food allergy. However, in light of a large literature linking the vitamin D levels to the onset of eczema and allergic diseases, this hormone must be considered as a further chance in the comprehension and treatment of atopic diseases. For this reason, there is an urgent need for well-planned randomized controlled trials on vitamin

\section{REFERENCES}

1. Sicherer SH, Sampson HA. Food allergy: a review and update on epidemiology, pathogenesis, diagnosis, prevention, and management. $J$ Allergy Clin Immunol. (2018) 141:41-58. doi: 10.1016/j.jaci.2017.11.003

2. Prescott SL, Pawankar R, Allen KJ, Campbell DE, Sinn JKH, Fiocchi A, et al. A global survey of changing patterns of food allergy burden in children. World Allergy Organ J. (2013) 6:21. doi: 10.1186/1939-4551-6-21

3. Hewison M. Vitamin D and innate and adaptive immunity. Vitam Horm. (2011). 86:23-62. doi: 10.1016/B978-0-12-386960-9.00002-2

4. Rosen CJ. Clinical practice. Vitamin D insufficiency. N Engl J Med. (2011) 364:248-54. doi: 10.1056/NEJMcp1009570

5. Poole A, Song Y, Brown H, Hart PH, Zhang G. Cellular and molecular mechanisms of vitamin D in food allergy. J Cell Mol Med. (2018) 22:32707. doi: $10.1111 / \mathrm{jcmm} .13607$

6. Wacker M, Holiack MF. Vitamin D-effects on skeletal and extraskeletal health and the need for supplementation. Nutrients. (2013) 5:11148. doi: 10.3390/nu5010111

7. Dimeloe S, Nanzer A, Ryanna K, Hawrylowicz C. Regulatory $\mathrm{T}$ cells, inflammation and the allergic response-the role of glucocorticoids and Vitamin D. J Steroid Biochem Mol Biol. (2010) 120:86-95. doi: 10.1016/j.jsbmb.2010.02.029

8. White JH. Vitamin D as an inducer of cathelicidin antimicrobial peptide expression: past, present and future. J Steroid Biochem Mol Biol. (2010) 121:234-8. doi: 10.1016/j.jsbmb.2010.03.034

9. Schwalfenberg GK. A review of the critical role of vitamin $D$ in the functioning of the immune system and the clinical implications of vitamin D deficiency. Mol Nutr Food Res. (2011) 55:96-108. doi: 10.1002/mnfr.201000174

10. Mullins RJ, Camargo CA. Shining a light on vitamin D and its impact on the developing immune system. Clin Exp Allergy. (2011) 41:7668. doi: $10.1111 / j .1365-2222.2011 .03742 . x$

11. Mora JR, Iwata M, Von Andrian UH. Vitamin effects on the immune system: vitamins A and D take centre stage. Nat Rev Immunol. (2008) 8:68598. doi: $10.1038 /$ nri2378

12. Wang TJ, Zhang F, Richards JB, Kestenbaum B, Van Meurs JB, Berry D, et al. Common genetic determinants of vitamin D insufficiency: a genome-wide association study. Lancet. (2010) 376:180-8. doi: 10.1016/S0140-6736(10)60588-0

13. Chun RF, Lauridsen AL, Suon L, Zella LA, Pike JW, Modlin RL, et al. Vitamin D-binding protein directs monocyte responses to 25-hydroxyand 1,25-dihydroxyvitamin D. J Clin Endocrinol Metab. (2010) 95:336876. doi: 10.1210/jc.2010-0195

14. Lehmann B, Meurer M. Vitamin D metabolism. Dermatol Ther. (2010) 23:212. doi: 10.1111/j.1529-8019.2009.01286.x

15. Principi N, Bianchini S, Baggi E, Esposito S. Implications of maternal vitamin D deficiency for the fetus, the neonate and the young infant. Eur J Nutr. (2013) 52:859-67. doi: 10.1007/s00394-012-0476-4

16. Christesen HT, Elvander C, Lamont RF, Jorgensen JS. The impact of vitamin $\mathrm{D}$ in pregnancy on extraskeletal health in children: a systematic review. Acta Obstet Gynecol Scand. (2012) 91:1368-80. doi: 10.1111/aogs.12006

17. Manson JE, Jones G, Kovacs CS, Ross AC, Gallo RL, Gallagher JC, et al. The 2011 dietary reference intakes for calcium and vitamin D: what
D supplementation, with particular regard to food allergy, to demonstrate that vitamin $\mathrm{D}$ might actually contribute to the prevention of allergic diseases.

\section{AUTHOR CONTRIBUTIONS}

GR, AG, and LB: conceptualization. AG, LB, and JC: resources. GR, AG, and RM: methodology and writing-review and editing. AG, LB, JC, MG, RM, and GR: writing-original draft preparation. RM and GR: supervision. All authors contributed to the article and approved the submitted version.

dietetics practitioners need to know. J Am Diet Assoc. (2011) 111:5247. doi: $10.1016 /$ j.jada.2011.01.004

18. Sepulveda-Villegas M, Elizondo-Montemayor L, Trevino V. Identification and analysis of 35 genes associated with vitamin D deficiency: a systematic review to identify genetic variants. J Steroid Biochem Mol Biol. (2020) 196:105516. doi: 10.1016/j.jsbmb.2019.105516

19. Turcanu V, Brough HA, Du Toit G, Foong RX, Marrs T, Santos AF, et al. Immune mechanisms of food allergy and its prevention by early intervention. Curr Opin Immunol. (2017) 48:92-98. doi: 10.1016/j.coi.2017.08.009

20. Hofmaier S, Comberiati P, Matricardi PM. Immunoglobulin G in IgEmediated allergy and allergen-specific immunotherapy. Eur Ann Allergy Clin Immunol. (2014) 46:6-11.

21. Chinthrajah RS, Hernandez JD, Boyd SD, Galli SJ, Nadeau KC. Molecular and cellular mechanisms of food allergy and food tolerance. J Allergy Clin Immunol. (2016) 137:984-97. doi: 10.1016/j.jaci.2016.02.004

22. Vassallo MF, Camargo CA. Potential mechanisms for the hypothesized link between sunshine, vitamin D, and food allergy in children. J Allergy Clin Immunol. (2010) 126:217-22. doi: 10.1016/j.jaci.2010.06.011

23. Lack G. Food allergy. N Engl J Med. (2008) 359:1252. doi: 10.1056/NEJMcp0800871

24. Chatenoud L, Bertuccio P, Turati F, Galeone C, Naldi L, Chatenoud L, et al. Markers of microbial exposure lower the incidence of atopic dermatitis. Allergy Eur J Allergy Clin Immunol. (2020) 75:104-15. doi: 10.1111/all.13990

25. Peroni DG, Piacentini GL, Cametti E, Chinellato I, Boner AL. Correlation between serum 25-hydroxyvitamin D levels and severity of atopic dermatitis in children. $\mathrm{Br} J$ Dermatol. (2011) 164:1078-82. doi: 10.1111/j.1365-2133.2010.10147.x

26. Sharief S, Jariwala S, Kumar J, Muntner P, Melamed ML. Vitamin D levels and food and environmental allergies in the United States: results from the national health and nutrition examination survey 2005-2006. J Allergy Clin Immunol. (2011) 127:1195-202. doi: 10.1016/j.jaci.2011.01.017

27. Mullins RJ, Camargo CA. Latitude, sunlight, vitamin D, and childhood food allergy/anaphylaxis. Curr Allergy Asthma Rep. (2012) 12:64-71. doi: 10.1007/s11882-011-0230-7

28. Kim S-H, Ban G-Y, Park H-S, Kim S, Ye Y-M. Regional differences in vitamin $\mathrm{D}$ levels and incidence of food-induced anaphylaxis in South Korea. Ann Allergy Asthma Immunol. (2016) 116:237-43.e1. doi: 10.1016/j.anai.2015.12.021

29. Kull I, Bergström A, Melén E, Lilja G, van Hage M, Pershagen G, et al. Earlylife supplementation of vitamins A and D, in water-soluble form or in peanut oil, and allergic diseases during childhood. J Allergy Clin Immunol. (2006) 118:1299-304. doi: 10.1016/j.jaci.2006.08.022

30. Camargo CA, Rifas-Shiman SL, Litonjua AA, Rich-Edwards JW, Weiss ST, Gold DR, et al. Maternal intake of vitamin D during pregnancy and risk of recurrent wheeze in children at $3 \mathrm{y}$ of age. Am J Clin Nutr. (2007) 85:788-95. doi: 10.1093/ajcn/85.3.788

31. Nwaru BI, Ahonen S, Kaila M, Erkkola M, Haapala AM, Kronberg-Kippilä C, et al. Maternal diet during pregnancy and allergic sensitization in the offspring by 5 yrs of age: a prospective cohort study. Pediatr Allergy Immunol. (2010) 21:29-37. doi: 10.1111/j.1399-3038.2009.00949.x

32. Liu X, Wang G, Hong $\mathrm{X}$, Wang $\mathrm{D}$, Tsai HJ, Zhang $\mathrm{S}$, et al. Gene-vitamin D interactions on food sensitization: a prospective 
birth cohort study. Allergy Eur J Allergy Clin Immunol. (2011) 66:1442-8. doi: 10.1111/j.1398-9995.2011.02681.x

33. Jones AP, Palmer D, Zhang G, Prescott SL. Cord blood 25-hydroxyvitamin D3 and allergic disease during infancy. Pediatrics. (2012) 130:e112835. doi: 10.1542/peds.2012-1172

34. Weisse K, Winkler S, Hirche F, Herberth G, Hinz D, Bauer M, et al. Maternal and newborn vitamin D status and its impact on food allergy development in the German LINA cohort study. Allergy Eur J Allergy Clin Immunol. (2013) 68:220-8. doi: 10.1111/all.12081

35. Allen KJ, Koplin JJ, Ponsonby AL, Gurrin LC, Wake M, Vuillermin $\mathrm{P}$, et al. Vitamin D insufficiency is associated with challenge-proven food allergy in infants. Allergy Clin Immunol. (2013) 131:1109-16.e1-6. doi: 10.1016/j.jaci.2013.01.017

36. Chiu C-Y, Yao T-C, Chen S-H, Tsai M-H, Tu Y-L, Hua M-C, et al. Low cord blood vitamin D levels are associated with increased milk sensitization in early childhood. Pediatr Allergy Immunol. (2014) 25:767-72. doi: 10.1111/pai.12304

37. Chawes BL, Bønnelykke K, Jensen PF, Schoos A-MM, Heickendorff L, Bisgaard H. Cord blood 25(OH)-vitamin D deficiency and childhood asthma, allergy and eczema: the COPSAC2000 birth cohort study. PLoS ONE. (2014) 9:e99856. doi: 10.1371/journal.pone.0099856

38. Hennessy Á, Hourihane JOB, Malvisi L, Irvine AD, Kenny LC, Murray DM, et al. Antenatal vitamin D exposure and childhood eczema, food allergy, asthma and allergic rhinitis at 2 and 5 years of age in the atopic disease-specific Cork BASELINE birth cohort study. Allergy Eur J Allergy Clin Immunol. (2018) 73:2182-91. doi: 10.1111/all.13590

39. Ercan N, Bostanci IB, Ozmen S, Tekindal MA. Is there an association between vitamin D levels and cow's milk protein allergy at infancy? Arch Argent Pediatr. (2019) 117:306-13. doi: 10.5546/aap.2019.eng.306

40. Neugut AI, Ghatak AT, Miller RL. Anaphylaxis in the United States: an investigation into its epidemiology. Arch Intern Med. (2001) 161:1521. doi: $10.1001 /$ archinte.161.1.15

41. Simons FER, Peterson S, Black CD. Epinephrine dispensing patterns for an out-of-hospital population: a novel approach to studying the epidemiology of anaphylaxis. J Allergy Clin Immunol. (2002) 110:64751. doi: 10.1067/mai.2002.127860

42. Camargo CA, Clark S, Kaplan MS, Lieberman P, Wood RA. Regional differences in EpiPen prescriptions in the United States: the potential role of vitamin D. J Allergy Clin Immunol. (2007) 120:131-6. doi: 10.1016/j.jaci.2007.03.049

43. Staples JA, Ponsonby AL, Lim LLY, McMichael AJ. Ecologic analysis of some immune-related disorders, including type 1 diabetes, in Australia: latitude, regional ultraviolet radiation, and disease prevalence. Environ Health Perspect. (2003) 111:518-23. doi: 10.1289/ehp.5941

44. Mullins RJ, Clark S, Camargo CA. Regional variation in epinephrine autoinjector prescriptions in Australia: more evidence for the vitamin Danaphylaxis hypothesis. Ann Allergy Asthma Immunol. (2009) 103:48895. doi: 10.1016/S1081-1206(10)60265-7

45. D’Auria E, Barberi S, Cerri A, Boccardi D, Turati F, Sortino S, et al. Vitamin D status and body mass index in children with atopic dermatitis: a pilot study in Italian children. Immunol Lett. (2017) 181:3135. doi: 10.1016/j.imlet.2016.11.004

46. Sheehan WJ, Graham D, Ma L, Baxi S, Phipatanakul W. Higher incidence of pediatric anaphylaxis in northern areas of the United States. J Allergy Clin Immunol. (2009) 124:850-2.e2. doi: 10.1016/j.jaci.2009.06.044

47. Douros K, Boutopoulou B, Fouzas S, Loukou I. Asthma and allergy 'Epidemic' and the role of vitamin D deficiency. In: Ultraviolet Light in Human Health, Diseases and Environment. Cham: Springer (2017). p. 169-83. doi: 10.1007/978-3-319-56017-5_14

48. Sardecka I, Łoś-Rycharska E, Gawryjołek J, Toporowska-Kowalska E, Krogulska A. FOXP3 expression, vitamins D and C in the prediction of tolerance acquisition in infants with cow's milk allergy. J Investig Allergol Clin Immunol. (2019) 30:182-90. doi: 10.18176/jiaci.0422
49. Baek JH, Shin YH, Chung IH, Kim HJ, Yoo E-G, Yoon JW, et al. The link between serum vitamin D level, sensitization to food allergens, and the severity of atopic dermatitis in infancy. J Pediatr. (2014) 165:849-54.e1. doi: 10.1016/j.jpeds.2014.06.058

50. Rosendahl J, Pelkonen AS, Helve O, Hauta-alus H, Holmlund-Suila E, Valkama S, et al. High-dose vitamin D supplementation does not prevent allergic sensitization of infants. J Pediatr. (2019) 209:13945.e1. doi: 10.1016/j.jpeds.2019.02.021

51. Guo Y, Yu L, Deng YH, Ke HJ, Wu JL. Associations between serum 25hydroxyvitamin D levels and allergic sensitization in early childhood. Allergol Immunopathol. (2020) 48:84-89. doi: 10.1016/j.aller.2019.06.016

52. Thorisdottir B, Gunnarsdottir I, Vidarsdottir AG, Sigurdardottir S, Birgisdottir BE, Thorsdottir I. Infant feeding, vitamin D and ige sensitization to food allergens at 6 years in a longitudinal icelandic cohort. Nutrients. (2019) 11:1-13. doi: 10.3390/nu11071690

53. De-Regil LM, Palacios C, Ansary A, Kulier R, Peña-Rosas JP. Vitamin D supplementation for women during pregnancy. Cochrane Syst Rev. (2016) CD008873. doi: 10.1002/14651858.CD008873.pub3

54. Mirzakhani H, Al-Garawi A, Weiss ST, Litonjua AA. Vitamin D and the development of allergic disease: how important is it? Clin Exp Allergy. (2015) 45:114-25. doi: 10.1111/cea.12430

55. Willits EK, Wang Z, Jin J, Patel B, Motosue M, Bhagia A, et al. Vitamin D and food allergies in children: a systematic review and meta-analysis. In: Allergy and Asthma Proceedings. Rhode: OceanSide Publications Inc. (2017). p. e21-8. doi: 10.2500/aap.2017.38.4043

56. Yepes-Nuñez JJ, Brozek JL, Fiocchi A, Pawankar R, Cuello-García C, Zhang Y, et al. Vitamin D supplementation in primary allergy prevention: systematic review of randomized and non-randomized studies. Allergy. (2018) 73:3749. doi: 10.1111/all.13241

57. Saggese G, Vierucci F, Prodam F, Cardinale F, Cetin I, Chiappini E, et al. Vitamin D in pediatric age: consensus of the Italian pediatric society and the Italian society of preventive and social pediatrics, jointly with the Italian federation of pediatricians. Ital J Pediatr. (2018) 44:51. doi: 10.1186/s13052-018-0488-7

58. Hawrylowicz C, Santos A. Vitamin D: can the sun stop the atopic epidemic? Curr Opin Allergy Clin Immunol. (2019) 20:181-7. doi: 10.1097/ACI.0000000000000613

59. Matsui T, Tanaka K, Yamashita H, Saneyasu K ichi, Tanaka H, Takasato Y, et al. Food allergy is linked to season of birth, sun exposure, and vitamin D deficiency. Allergol Int. (2019) 68:172-7. doi: 10.1016/j.alit.2018.12.003

60. Hyppönen E, Berry DJ, Wjst M, Power C. Serum 25-hydroxyvitamin D and IgE-a significant but nonlinear relationship. Allergy Eur J Allergy Clin Immunol. (2009) 64:613-20. doi: 10.1111/j.1398-9995.2008.01865.x

61. Mullins RJ, Clark S, Wiley V, Eyles D, Camargo CA. Neonatal vitamin D status and childhood peanut allergy: a pilot study. Ann Allergy Asthma Immunol. (2012) 109:324-8. doi: 10.1016/j.anai.2012.07.009

62. Camargo CA, Ingham T, Wickens $\mathrm{K}$, Thadhani RI, Silvers $\mathrm{KM}$, Epton MJ, et al. Vitamin D status of newborns in New Zealand. Br J Nutr. (2010) 104:1051-7. doi: 10.1017/S00071145100 01674

Conflict of Interest: The authors declare that the research was conducted in the absence of any commercial or financial relationships that could be construed as a potential conflict of interest.

Copyright () 2020 Giannetti, Bernardini, Cangemi, Gallucci, Masetti and Ricci. This is an open-access article distributed under the terms of the Creative Commons Attribution License (CC BY). The use, distribution or reproduction in other forums is permitted, provided the original author(s) and the copyright owner(s) are credited and that the original publication in this journal is cited, in accordance with accepted academic practice. No use, distribution or reproduction is permitted which does not comply with these terms. 